\title{
Ecological traits of Caribbean sea anemones and symbiotic crustaceans
}

\author{
P. Briones-Fourzán ${ }^{1, *}$, M. Pérez-Ortiz ${ }^{2}$, F. Negrete-Soto ${ }^{1}$, C. Barradas-Ortiz ${ }^{1}$, \\ E. Lozano-Álvarez ${ }^{1}$
}

${ }^{1}$ Unidad Académica de Sistemas Arrecifales, Instituto de Ciencias del Mar y Limnología, Universidad Nacional Autónoma de México, Puerto Morelos, Quintana Roo 77580, Mexico

${ }^{2}$ Posgrado en Ciencias del Mar y Limnología, Universidad Nacional Autónoma de México, México, Distrito Federal 04360, Mexico

\begin{abstract}
In Caribbean coral reefs, many crustacean species associate with sea anemones, but only a few are anemone symbionts. We examined several ecological traits of 3 anemone species (Bartholomea annulata, Condylactis gigantea, Lebrunia danae) and their crustacean symbionts (6 species) on a coral reef at Puerto Morelos, Mexico. On average, C. gigantea was the largest and $B$. annulata the most abundant of the 3 anemone species. Season did not affect the density distribution of any species, whereas reef zone (back reef, fore reef, reef channels) significantly affected density and mean size of $B$. annulata and $C$. gigantea, but only density of $L$. danae. The probability of harboring crustaceans increased with anemone size in all species, but varied with reef zone and season in $B$. annulata only. These patterns may be due to different microhabitat requirements, reproductive strategies, or photosynthetic plasticity of dinoflagellate endosymbionts among hosts, and different flow regimes among reef zones. Alpheus armatus and Ancylomenes pedersoni were strongly associated with $B$. annulata, and Periclimenes rathbunae with $L$. danae. Thor amboinensis and Mithraculus cinctimanus occurred more often in C. gigantea, while P. yucatanicus was more evenly associated with the 3 hosts. Only Ancylomenes pedersoni and T. amboinensis occurred in conspecific groups more often than expected by chance. Commensal complexes of up to 3 symbiont species occurred in all host species, with symbionts that typically used different parts of the host coexisting more frequently. These results provide a baseline to assess the potential influence of local and global anthropogenic stressors on anemone-crustacean symbioses.
\end{abstract}

KEY WORDS: Symbiosis $\cdot$ Coral reef $\cdot$ Mexico $\cdot$ Commensal complex $\cdot$ Puerto Morelos

\section{INTRODUCTION}

Coral reefs support the highest biodiversity of all marine ecosystems, with invertebrates contributing dominantly to this condition (Reaka et al. 2008). In the complex community networks typical of coral reefs, an important ecological role is played by many invertebrates that may serve as 'habitat providers' (i.e. species that offer structure or substrate that other species may live in or on). Habitat providers are ubiquitous and include numerous spe- cies of sponges, hard and soft corals, tube-dwelling polychaetes, ascidians, echinoderms, molluscs, and sea anemones. Equally diverse are the organisms that live in or on habitat providers, which include a vast array of invertebrates and fishes (review in Glynn \& Enochs 2011).

Organisms that associate with habitat providers ('hosts') may obtain a variety of benefits, including physical shelter from predation, camouflage, stability, range expansion, or advantageous positioning. For example, the nematocyst-armed tentacles of sea 
anemones provide protection from predation to many crustaceans (Fautin et al. 1995, Wirtz 1997, Khan et al. 2004) that acquire immunity from the toxic compounds produced by their hosts through a process known as acclimation (Levine \& Blanchard 1980, Crawford 1992, Giese et al. 1996). The general term 'crustacean associates' refers to any crustacean found in, on, or very close to an anemone, but such crustaceans can be categorized into 2 types: 'facultative associates', i.e. crustaceans that are primarily free-living but may briefly associate with anemones, and 'symbionts', i.e. crustaceans wherein the association with the host is not random or occasional, but long-term (Ross 1983, Gwaltney \& Brooks 1994, Calado et al. 2002).

In the wider Caribbean region, some field studies have focused on the abundance, distribution, or population dynamics of anemones without regard to their symbionts (e.g. Sebens 1976, Barrios-Suárez et al. 2002, Herrera-Moreno \& Betancourt-Fernández 2002, Nelsen 2008). Other studies have mainly focused on ecological traits of the crustacean symbionts, such as degree of host specificity (e.g. Knowlton 1980, Gwaltney \& Brooks 1994), distribution patterns (e.g. Hayes \& Trimm 2008, Silbiger \& Childress 2008), or demography and behavior (e.g. Mahnken 1972, Sargent \& Wagenbach 1975, Patton 1979, Williams \& Bunkley-Williams 2000, Huebner \& Chadwick 2012a). Others have contrasted ecological traits of anemones with those of their crustacean symbionts, but with emphasis on a particular host species (e.g. Herrnkind et al. 1976, Stanton 1977 , Huebner \& Chadwick 2012b) or one or a few selected symbiont species (e.g. Mahnken 1972, Nizinski 1989, Silbiger \& Childress 2008). However, because most crustacean symbionts of Caribbean anemones are host-generalists (e.g. see Silbiger \& Childress 2008), their abundance and distribution at the local scale may depend to some extent on the ecological traits of multiple host anemone species, their use of space provided by the host, and intra- and interspecific interactions with other crustacean associates.

To provide some insight into these issues, we examined several ecological traits of multiple species of host anemones and their crustacean symbionts in one of the most intensely studied Caribbean coral reef systems in Mexico, the Puerto Morelos coral reef system (PMCR) (Rodríguez-Martínez 2008). Nearly $20 \mathrm{yr}$ of monitoring of environmental variables and ecological features of these coral reef and sea grass communities provides continuously updated information on environmental characteristics prevailing in different parts of the PMCR (e.g. Ruiz-Rentería et al. 1998, Jordán-Dahlgren \& Rodríguez-Martínez 2003, Coronado et al. 2007, Rodríguez-Martínez et al. 2010, van Tussenbroek 2011).

Among the 13 species of sea anemones registered in the PMCR (González-Muñoz 2009), 3 actiniarians widely known as hosts for crustaceans are particularly ubiquitous: the corkscrew anemone Bartholomea annulata (Family Aiptasiidae), the giant anemone Condylactis gigantea (Actiniidae), and the branching anemone Lebrunia danae (Aliciidae). In the present study, we examine several ecological traits of these 3 host anemone species, and of the full array of their crustacean symbionts. We were particularly interested in examining the density and size distribution of each host species in distinct reef environments, and the degree to which these traits varied on a seasonal basis. Our aim was to assess the relative importance of these anemone species in providing habitat for crustacean symbionts in reef zones with different environmental features.

\section{MATERIALS AND METHODS}

\section{Study area}

The PMCR (centered at $20^{\circ} 51^{\prime} \mathrm{N}, 86^{\circ} 53^{\prime} \mathrm{W}$ ) is located near the town of Puerto Morelos on the NE coast of the Yucatan Peninsula (state of Quintana Roo, Mexico). It is an extended fringing reef composed of a series of reef patches differing in size and structural complexity (Fig. 1). The reef is separated from the shoreline by a narrow ( 500 to $1500 \mathrm{~m}$ in width) and shallow ( $<5 \mathrm{~m}$ in depth) reef lagoon characterized by calcareous sand stabilized by sea grass meadows (Ruiz-Rentería et al. 1998). The PMCR has a well-developed back reef and reef crest, and a relatively flat fore reef that descends gradually to 20-25 m into an extensive sand platform (JordánDahlgren 1989, Rodríguez-Martínez et al. 2010). The back reef is dominated by the scleractinians Acropora palmata and Montastraea annularis, and varies from shallow (2 to $3 \mathrm{~m}$ ) protected flat areas, to deeper ( 5 to $7 \mathrm{~m}$ ), relatively more exposed areas with higher relief. The fore reef also varies from areas of hard substrate with a relatively gentle slope, colonized by many small scleractinian colonies, gorgonians, and sponges, to high relief areas where large scleractinians dominate (Jordán-Dahlgren \& Rodríguez-Martínez 2003). A detailed study on the physical oceanography of this coral reef system found that the exchange of water between the reef lagoon and the adjacent ocean is mainly driven by the circulation 


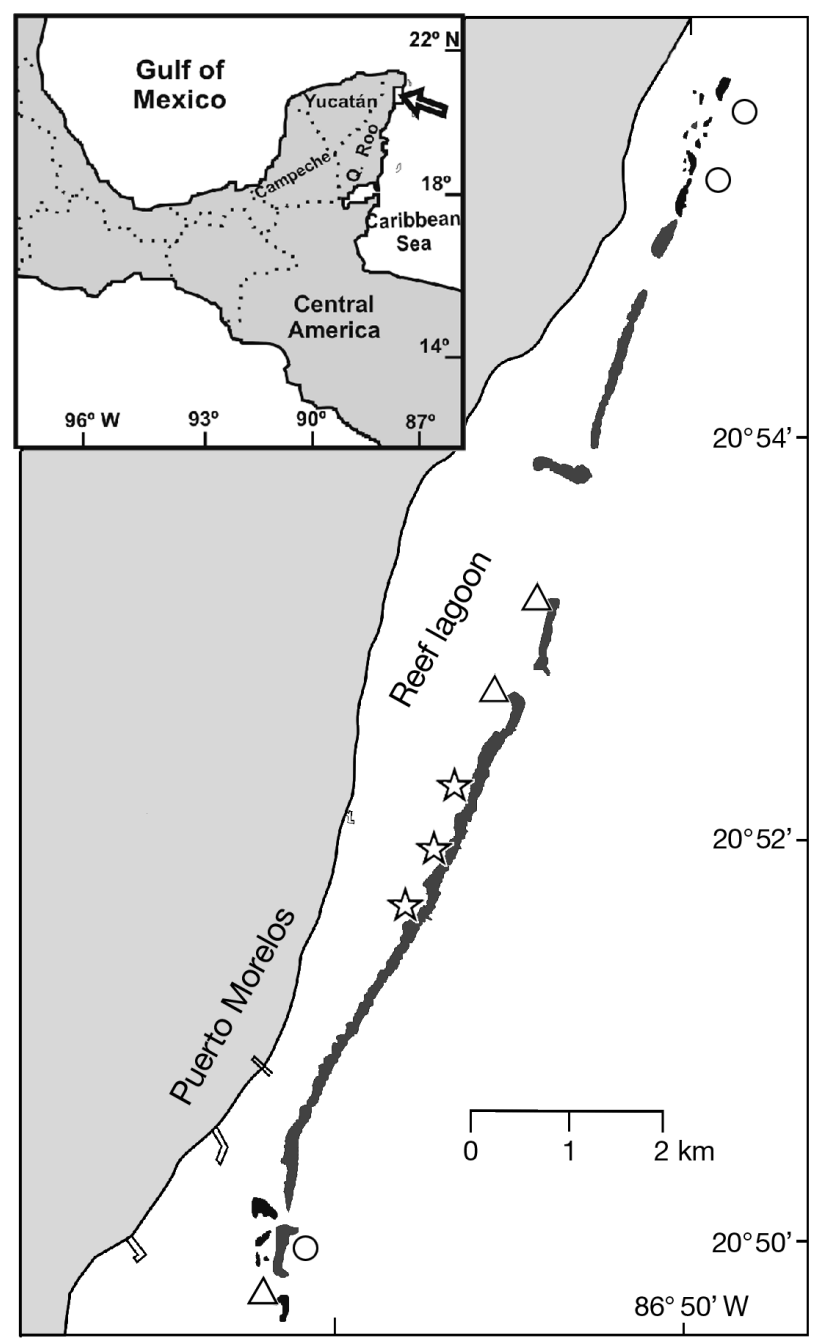

Fig. 1. The Puerto Morelos coral reef system. Black structures $=$ coral reef patches. Symbols $=$ location of 9 fixed sampling sites ( 2 : back-reef site; O: fore-reef site; $\Delta$ : reef-channel site). Inset: location of Puerto Morelos (arrow) in Mexico

induced by surface waves overtopping the reef and spilling water into the lagoon, with the water eventually leaving the lagoon through the reef channels (Coronado et al. 2007).

\section{Sampling design}

To account for the local hydrodynamic regime, and for differences in structural complexity as well as environmental gradients along and across the reef tract, we established 3 replicate fixed sites in each of 3 reef zones: back reef, fore reef, and reef channels (Fig. 1). Each site measured $50 \times 50 \mathrm{~m}$ (i.e. 0.25 ha) and was delineated with flag tags. The back-reef sites (1.8 to $2.0 \mathrm{~m}$ depth) were located along the lee- ward side of a large, elongated reef patch that extends for $\sim 6 \mathrm{~km}$ (Fig. 1). The fore-reef sites (8.0 to $10.2 \mathrm{~m}$ depth) were located on the exposed side of 3 relatively well-developed reef patches. The reef channel sites (5.0 to $7.0 \mathrm{~m}$ depth) were located on relatively exposed, deeper areas of the back reef adjacent to 3 reef channels (Fig. 1).

Using SCUBA, we surveyed the entire area of each site for individuals of Bartholomea annulata, Condylactis gigantea, and Lebrunia danae during 4 consecutive seasons starting in the spring of 2007 (spring: 12 April to 4 May; summer: 10 to 30 September; autumn: 21 November to 4 December 2007; winter: 13 February to 3 March 2008). All surveys were conducted between 10:00 and 13:00 h. Within each site, we counted all anemones, and measured the length $(\mathrm{L})$ and width $(\mathrm{W})$ of the tentacle crown of each individual with a metal ruler $( \pm 0.5 \mathrm{~cm})$ to estimate the tentacle crown surface area $(\mathrm{TCSA}=\pi \times 0.5 \mathrm{~L} \times$ $0.5 \mathrm{~W}$; Hattori 2002). We also counted and identified in situ the crustaceans associated with each anemone, and recorded their positions relative to the host ('on host': on the tentacle crown; 'under host': under the tentacle crown; 'near host': on the substrate surrounding the anemone, within a radius of $\sim 10 \mathrm{~cm}$ ).

\section{Statistical analyses}

Variability in anemone density and size (TCSA)

We subjected the anemone density data (number of individuals $0.25 \mathrm{ha}^{-1}$ ) to a factorial repeated-measures ANOVA (RM-ANOVA). The main (fixed) factors were anemone species (AS, with 3 levels) and reef zone (RZ, with 3 levels: back-reef, reef channels, and fore-reef, and 3 replicate sites per level). Time ( $\mathrm{T}$, with 4 levels corresponding to the 4 seasons) was the repeated measure. The data were previously transformed to $\ln (n+1)$ to meet the assumption of homogeneity of variances as assessed with Levene tests. In repeated-measures studies, the data may be auto-correlated (i.e. non-independent) across times. To overcome this problem, we assessed the degree to which the assumption of sphericity was violated with a Mauchly's test and, if necessary, adjusted the degrees of freedom of $\mathrm{T}$ and its residuals with the Huynh-Feldt correction (Howell 2002).

Because the 3 anemone species were not present on all replicate sites of each zone at all seasons (precluding the use of RM-ANOVA), the data on size (TCSA in $\mathrm{cm}^{2}$ ) for each species were pooled by 
reef zone and subjected to a factorial ANOVA to test the effects of AS and RZ on mean size of anemones (Underwood 1981). The data were previously transformed to $\ln (\mathrm{TCSA})$ to increase homogeneity of variances, as assessed with Levene tests.

\section{Distribution of crustaceans among host anemones}

We used 3 logistic regression analyses (1 per anemone species) to test the effects of size (TCSA, continuous factor), time, and reef zone (categorical factors with 4 and 3 levels, respectively) on their probabilities of harboring crustaceans (Quinn \& Keough 2002). The binary response variable was the absence or presence of at least 1 crustacean associate. We then used a simple linear regression to examine the relationship between TCSA and the number of crustacean associates.

To examine the distribution of crustaceans among conspecific hosts, we computed the mean number of crustaceans per anemone (and the corresponding variance), and subjected the count data to a $\chi^{2}$ goodness-of-fit test to a Poisson (random) distribution. If the test was significant, we further subjected the data to a $\chi^{2}$ goodness-of-fit test to a negative binomial distribution. Finally, we categorized the crustaceans into symbionts and facultative associates based on previous knowledge on the types of habitats used by each species (e.g. Chace 1972, Wagner 1990, MonroyVelázquez 2000, Briones-Fourzán \& Lozano-Álvarez 2002, Silbiger \& Childress 2008), and used exclusively the symbiont species in the following analyses.

Density of crustacean symbionts, affinity for hosts, and use of space provided by host

The density of symbionts (number of individuals $0.25 \mathrm{ha}^{-1}$ ) was examined with a factorial RMANOVA. The main (fixed) factors were symbiotic crustacean species (CS, with 6 levels corresponding to the 6 symbiotic species) and RZ. T was the repeated measure. The data were previously transformed to $\ln (n+1)$ to increase homogeneity of variances, and the degree to which the assumption of sphericity was violated was assessed with Mauchly's test.

For each symbiont species, we used separate $\chi^{2}$ goodness-of-fit tests to compare the proportions of individuals distributed among the 3 host species and the 3 positions relative to the host. Seasonal variability in these traits was separately examined with a
$3 \times 4$ contingency table ( 3 levels for the corresponding categorical factor $\times 4$ seasons).

Conspecific groups and commensal complexes

To assess the tendency of symbionts to form groups, we computed the number of conspecific symbionts that were alone or in groups of 2,3 , etc., in the same host, and compared the frequency data with a truncated Poisson (random) distribution using $\chi^{2}$ (Cohen 1960). We then computed all commensal complexes (2 or more species of symbionts coexisting in the same host) for each host species, and explored how coexisting species used the space provided by the host (e.g. Stanton 1977).

\section{RESULTS}

\section{Host anemones}

Anemone density and size

The data on anemone density did not violate the assumption of independent samplings across time (Mauchly test, $W=0.863, \chi^{2}{ }_{5}=2.456, \mathrm{p}=0.783$; Huynh-Feldt correction $=1$ ). Density varied significantly with AS and T, and there were interaction effects between AS $\times$ RZ and T $\times$ RZ (Table 1). The overall density (all means \pm SE) of Bartholomea annulata $\left(23.2 \pm 3.1\right.$ ind. $\left.0.25 \mathrm{ha}^{-1}\right)$ was almost twice as high as that of Lebrunia danae $\left(13.5 \pm 3.0\right.$ ind. $\left.0.25 \mathrm{ha}^{-1}\right)$ and over 4 times as high as that of Condylactis gigantea $\left(5.3 \pm 0.9\right.$ ind. $\left.0.25 \mathrm{ha}^{-1}\right)$. In particular, the density of

Table 1. Bartholomea annulata, Condylactis gigantea, and Lebrunia danae. Repeated-measures ANOVA of anemone density (ln [n+1] $0.25 \mathrm{ha}^{-1}$ ) with anemone species (AS) and reef zone (RZ; back reef, reef channels, fore reef) over time ( $T$; spring, summer, autumn, and winter)

\begin{tabular}{|lrrrr|}
\hline Effect & df & \multicolumn{1}{c}{ MS } & $F$ & p \\
\hline Intercept & 1 & 480.425 & 179.922 & $<0.001$ \\
AS & 2 & 28.505 & 10.675 & 0.001 \\
RZ & 2 & 1.603 & 0.600 & 0.559 \\
AS $\times$ RZ & 4 & 12.250 & 4.588 & 0.010 \\
Error & 18 & 0.504 & & \\
T & 3 & 0.305 & 4.130 & 0.010 \\
T $\times$ AS & 6 & 0.104 & 1.415 & 0.226 \\
T $\times$ RZ & 6 & 0.247 & 3.343 & 0.007 \\
T $\times$ AS $\times$ RZ & 12 & 0.041 & 0.550 & 0.871 \\
Error & 54 & 0.014 & & \\
\hline
\end{tabular}


B. annulata was highest in the reef channels $(35.9 \pm$ 1.2 ind. $0.25 \mathrm{ha}^{-1}$, averaged across seasons; Fig. 2a), while densities of $C$. gigantea $\left(1.2 \pm 0.2\right.$ ind. $\left.0.25 \mathrm{ha}^{-1}\right)$ and $L$. danae $\left(1.3 \pm 0.1\right.$ ind. $\left.0.25 \mathrm{ha}^{-1}\right)$ were lowest in the reef channels and on the back reef, respectively (Fig. 2b,c). The density distribution of each species by reef zone remained rather stable over time $(\mathrm{T} \times \mathrm{AS} \times$ RZ; Table 1). However, within each reef zone during any season, there was considerable variation in density among replicate sites, especially for $C$. gigantea on the fore reef (where this species was generally rare in 2 of the 3 sites) and $L$. danae on the back reef (Fig. 3), indicating a rather patchy distribution.

The overall range in TCSA was 3.1 to $380.1 \mathrm{~cm}^{2}$ for Bartholomea annulata, 2.4 to $276.5 \mathrm{~cm}^{2}$ for Lebrunia danae, and 7.1 to $452.4 \mathrm{~cm}^{2}$ for Condylactis gigantea. Mean TCSA (averaged across seasons) varied signif- icantly among species $\left(F_{2,27}=31.581, \mathrm{p}<0.001\right)$ and reef zones $\left(F_{2,27}=20.330, \mathrm{p}<0.001\right)$, with a significant interaction effect between these 2 variables $\left(F_{4,27}=8.714, \mathrm{p}<0.001\right)$. The TCSA (all means $\pm \mathrm{SE}$ ) of $C$. gigantea $\left(109.2 \pm 17.4 \mathrm{~cm}^{2}\right)$ was twice as large as those of $L$. danae $\left(56.9 \pm 4.1 \mathrm{~cm}^{2}\right)$ or $B$. annulata $\left(50.6 \pm 4.1 \mathrm{~cm}^{2}\right)$. However, the TCSA of B. annulata was significantly larger on the fore reef $(66.1 \pm$ $\left.4.1 \mathrm{~cm}^{2}\right)$ than in the reef channels $\left(46.3 \pm 4.8 \mathrm{~cm}^{2}\right)$ or on the back reef $\left(39.2 \pm 3.3 \mathrm{~cm}^{2}\right)$ (Fig. 4), and the TCSA of C. gigantea decreased significantly from the fore reef $\left(173.0 \pm 27.6 \mathrm{~cm}^{2}\right)$ to the back reef $(105.0 \pm$ $\left.5.0 \mathrm{~cm}^{2}\right)$ to the reef channels $\left(49.5 \pm 2.7 \mathrm{~cm}^{2}\right.$; Fig. 4$)$, whereas the TCSA of $L$. danae did not vary significantly with reef zone (Fig. 4).

The population size distribution of each anemone species in increments of $25 \mathrm{~cm}^{2}$ TCSA revealed that,
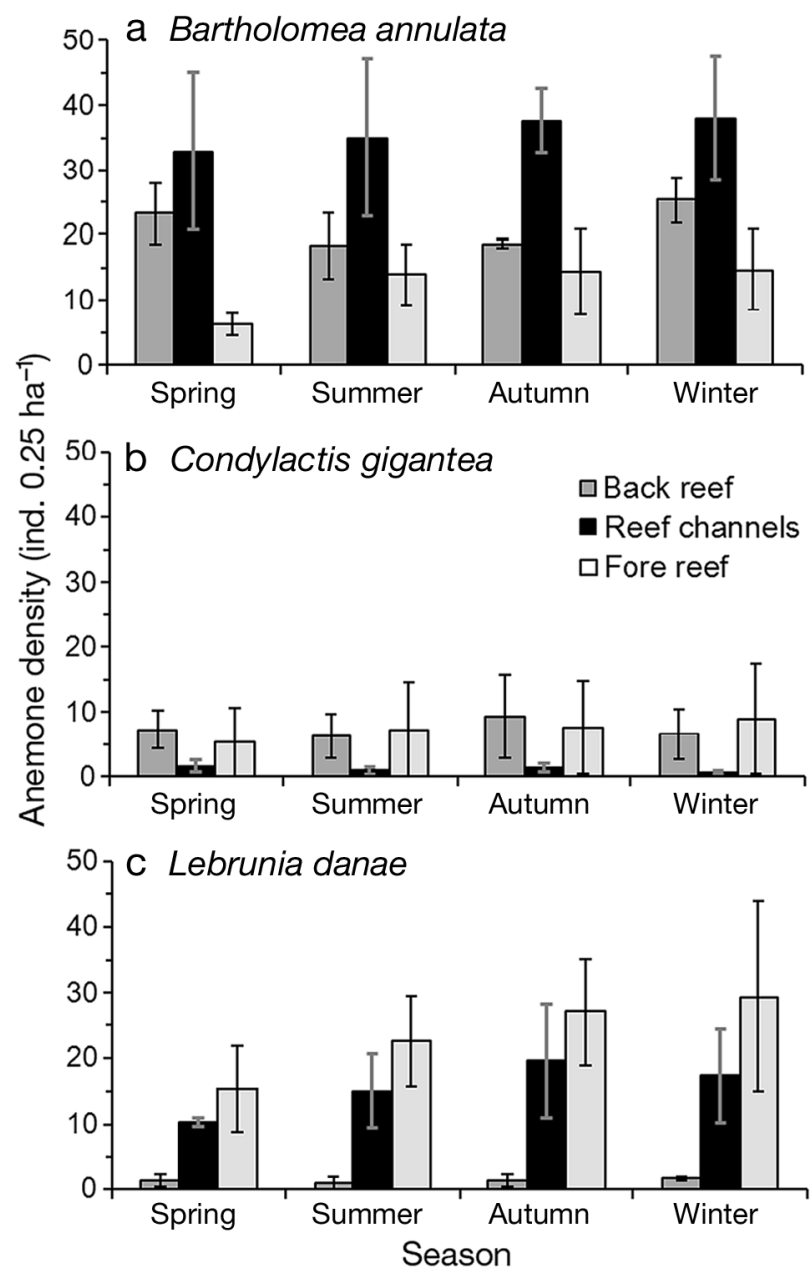

Fig. 2. Bartholomea annulata, Condylactis gigantea, and Lebrunia danae. Density (mean $\pm \mathrm{SE}$ ) of (a) B. annulata, (b) C. gigantea, and (c) L. danae in 3 reef zones (back reef, reef channels, fore reef, 3 replicate sites per zone) at 4 seasons (spring, summer, and autumn 2007, and winter 2008)

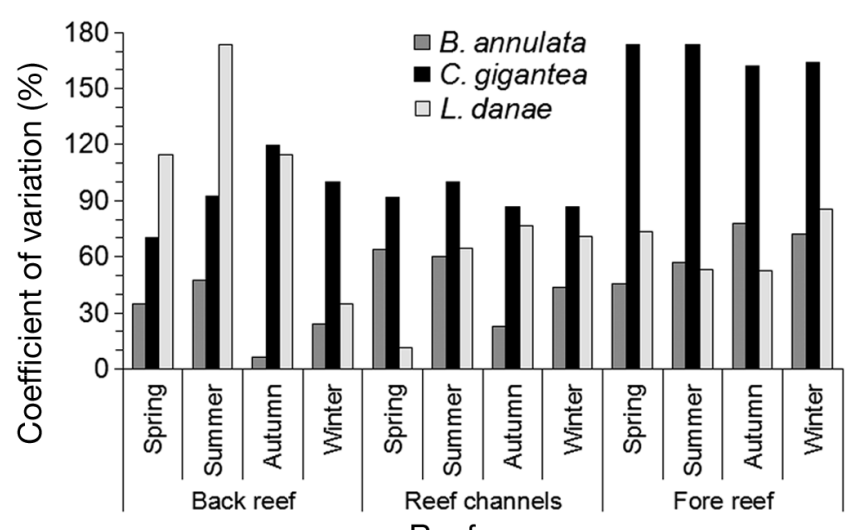

Fig. 3. Bartholomea annulata, Condylactis gigantea, and Lebrunia danae. Coefficient of variation (\%) of anemone density among replicate sites for each reef zone and season

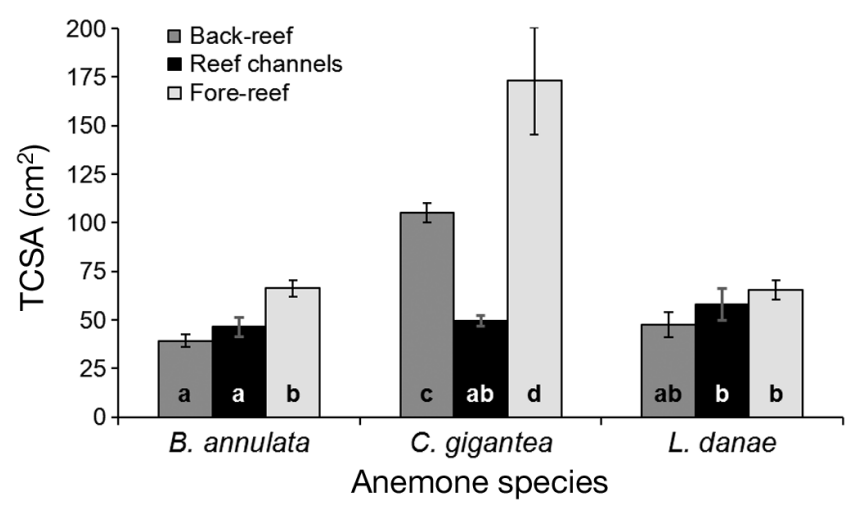

Fig. 4. Bartholomea annulata, Condylactis gigantea, and Lebrunia danae. Size (tentacle crown surface area, TCSA, mean $\pm \mathrm{SE}$ ) measured in the back reef, reef channels, and fore reef zones ( 3 replicate sites per zone). Similar letters in columns denote statistically similar means 
for Bartholomea annulata, the mode increased from the back reef $\left(\leq 25 \mathrm{~cm}^{2}\right)$ to the reef channels (25 to $50 \mathrm{~cm}^{2}$ ) to the fore reef (50 to $75 \mathrm{~cm}^{2}$; Fig. 5a). Lebrunia danae exhibited a single mode in the size class 25 to $50 \mathrm{~cm}^{2}$ in all 3 reef zones, albeit more markedly in the back reef (Fig. 5b). In contrast, Condylactis gigantea exhibited a multimodal size distribution in all 3 reef zones (Fig. 5c).

\section{Distribution of crustaceans among host anemones}

Across the study period, crustaceans were present in $72.8 \%$ of individuals of Bartholomea annulata $(\mathrm{n}=$ 835), $70.7 \%$ of Condylactis gigantea ( $\mathrm{n}=191)$, and $27.2 \%$ of Lebrunia danae $(\mathrm{n}=486)$. In $B$. annulata, the probability of harboring crustaceans increased significantly with TCSA, and was also affected by
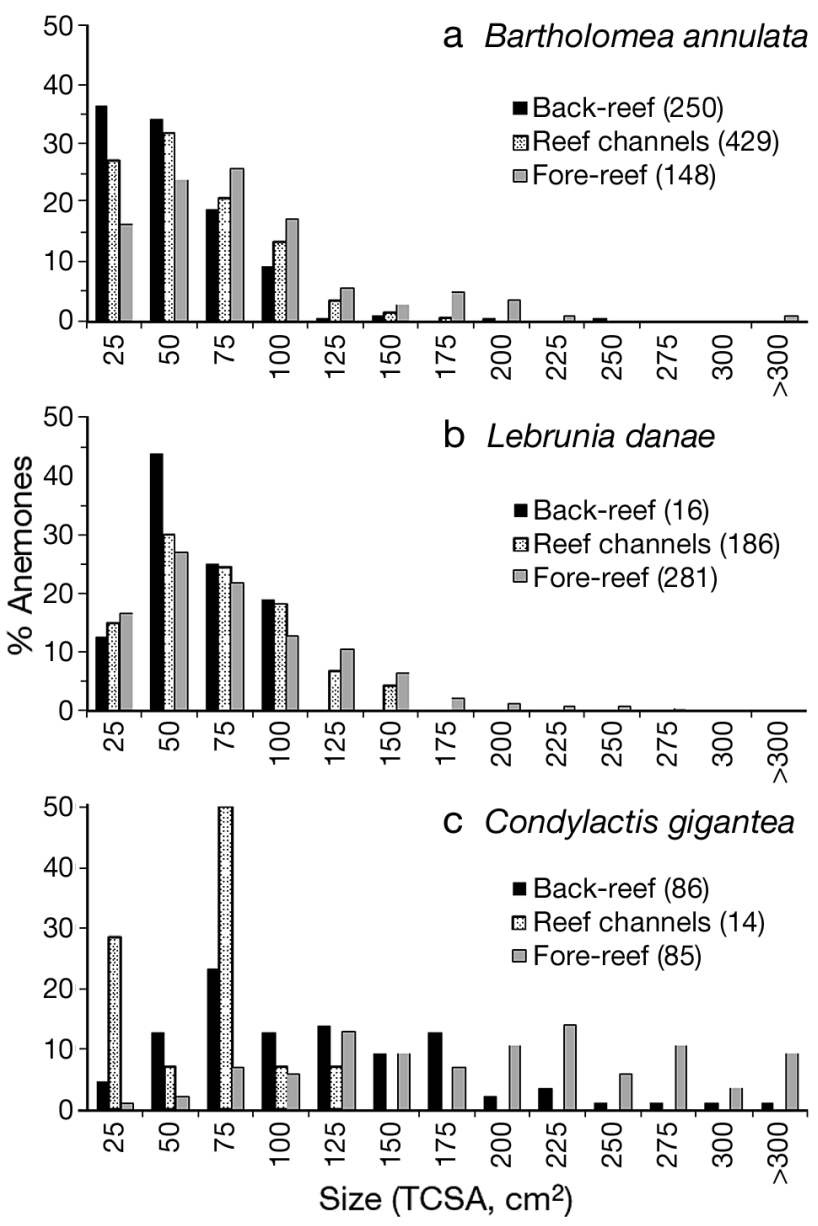

Fig. 5. Bartholomea annulata, Lebrunia danae, and Condylactis gigantea. Size distribution (tentacle crown surface area, TCSA) of individuals of (a) B. annulata, (b) L. danae, and (c) C. gigantea in the back reef, reef channels, and fore reef zones. Numbers on the $x$-axis: end points of intervals. Numbers in (): sample size reef zone and season (Table 2). In particular, the probability was significantly lower in the reef channels (Table 2). By contrast, the only factor significantly (positively) affecting the probability of finding crustaceans in C. gigantea and L. danae was TCSA (Table 2).

Per individual anemone, Bartholomea annulata and Condylactis gigantea harbored from 0 to 7 individual crustaceans, and Lebrunia danae from 0 to 5. In all 3 host species, there was a significant (all p-values $<0.001$ ) but rather weak relationship between number of crustaceans and TCSA (B. annulata: $\mathrm{r}^{2}=0.115$, $\mathrm{n}=825 ; C$. gigantea: $\mathrm{r}^{2}=0.173, \mathrm{n}=187 ; L$. danae: $\left.\mathrm{r}^{2}=0.055, \mathrm{n}=484\right)$. The distribution of crustaceans among conspecific hosts differed significantly from random in all cases (Table 3). In B. annulata, the count data were dominated by solitary crustaceans (i.e. 1 per host) and the mean was greater than the variance, indicating under-dispersion (Table 3). By contrast, in C. gigantea and L. danae, the variance was greater than the mean, indicating over-dispersion, and the negative binomial distribution fitted the distribution of crustaceans well (Table 3).

\section{Diversity of crustacean associates}

In total, we found 1371 individual crustaceans on these anemones, of which 1283 (93.8\%) belonged to 6 species of symbionts: the alpheid shrimp Alpheus armatus, the palaemonid shrimps Ancylomenes pedersoni (previously known as Periclimenes pedersoni; Okuno \& Bruce 2010), Periclimenes yucatanicus and $P$. rathbunae, the hippolytid shrimp Thor amboinensis, and the majid crab Mithraculus cinctimanus (Table 4). The rest (86 individuals, $6.2 \%$ of the total) belonged to 9 species of facultative associates (the shrimps Stenopus hispidus, Brachycarpus biunguiculatus, and Cinetorhynchus rigens, and the crabs Stenorhynchus seticornis, Mithraculus sculptus, Mithraculus forceps, Mithrax pilosus, Mithrax sp., and Macrocoeloma trispinosum; Table 4).

\section{Crustacean symbionts}

Density and distribution of crustacean symbionts

Data on the density of crustacean symbionts did not violate the assumption of independent samplings across time (Mauchly test, $\chi_{5}^{2}=10.267, \mathrm{p}=0.067$; Huynh-Feldt correction $=1$ ). Density varied significantly with CS and T, and there was a significant in- 
Table 2. Bartholomea annulata, Condylactis gigantea, and Lebrunia danae. Estimates of separate logistic regression analyses testing effects of size (tentacle crown surface area, TCSA in $\mathrm{cm}^{2}$ ), reef zone (back reef, reef channels, and fore reef; reference level: fore reef), and season (reference level: winter) on the probability of finding at least 1 crustacean associate on each species of host anemone

\begin{tabular}{|lrrrrr|}
\hline Effect & Estimate \pm SE & $\begin{array}{c}\text { Wald } \\
\text { statistic }\end{array}$ & df & $p$ & $\begin{array}{c}\text { Odds ratio } \\
(95 \% \mathrm{CI})\end{array}$ \\
\hline B. annulata & & & & & \\
Size & $0.026 \pm 0.004$ & 48.689 & 1 & $<0.001$ & $1.03(1.03-1.05)$ \\
Zone: Back reef & $0.189 \pm 0.142$ & 1.775 & 1 & 0.183 & $1.21(0.91-1.59)$ \\
Reef channels & $-0.383 \pm 0.124$ & 9.556 & 1 & 0.002 & $0.68(0.53-0.87)$ \\
Season: Spring & $0.071 \pm 0.206$ & 0.118 & 1 & 0.731 & $1.07(0.72-1.61)$ \\
Summer & $0.435 \pm 0.197$ & 4.862 & 1 & 0.027 & $1.54(1.05-2.27)$ \\
Autumn & $-0.358 \pm 0.162$ & 4.861 & 1 & 0.027 & $0.70(0.51-0.96)$ \\
C. gigantea & & & & & \\
Size & $0.011 \pm 0.004$ & 9.386 & 1 & 0.002 & $1.01(1.00-1.02)$ \\
Zone: Back reef & $-0.059 \pm 0.294$ & 0.040 & 1 & 0.841 & $0.94(0.53-1.68)$ \\
Reef channels & $-0.759 \pm 0.456$ & 2.767 & 1 & 0.096 & $0.47(0.19-1.14)$ \\
Season: Spring & $0.428 \pm 0.437$ & 0.958 & 1 & 0.328 & $1.53(0.65-3.61)$ \\
Summer & $0.132 \pm 0.488$ & 0.073 & 1 & 0.786 & $1.14(0.44-2.97)$ \\
Autumn & $-0.549 \pm 0.406$ & 1.823 & 1 & 0.177 & $0.58(0.26-1.28)$ \\
L. danae & & & & & \\
Size & $0.010 \pm 0.003$ & 12.867 & 1 & $<0.001$ & $1.01(1.00-1.02)$ \\
Zone: Back reef & $0.252 \pm 0.386$ & 0.426 & 1 & 0.514 & $1.29(0.60-2.74)$ \\
Reef channels & $0.012 \pm 0.229$ & 0.003 & 1 & 0.958 & $1.01(0.65-1.59)$ \\
Season: Spring & $-0.276 \pm 0.371$ & 0.551 & 1 & 0.458 & $0.76(0.37-1.57)$ \\
Summer & $0.538 \pm 0.366$ & 2.160 & 1 & 0.142 & $1.71(0.84-3.51)$ \\
Autumn & $0.239 \pm 0.327$ & 0.534 & 1 & 0.465 & $1.27(0.67-2.41)$ \\
\hline & & & & & \\
\hline
\end{tabular}

Table 3. Bartholomea annulata, Condylactis gigantea, and Lebrunia danae. Statistics and goodness-of-fit tests for types of distributions of crustaceans among individuals of each host anemone species

\begin{tabular}{|lccc|}
\hline & \multicolumn{3}{c|}{ Host anemone species } \\
\cline { 2 - 4 } & B. annulata & C. gigantea & L. danae \\
\hline Total N & 835 & 191 & 486 \\
N with crustaceans (\%) & $608(72.8)$ & $135(70.7)$ & $132(27.2)$ \\
Mean no. of crustaceans & 1.04 & 1.70 & 0.37 \\
Variance & 0.83 & 3.26 & 0.52 \\
Variance/Mean & 0.798 & 1.918 & 1.475 \\
Goodness of fit to & $\chi^{2}{ }_{4}=80.10$, & $\chi^{2}{ }_{4}=49.46$, & $\chi^{2}{ }_{2}=16.92$, \\
Poisson distribution & $\mathrm{p}<0.001$ & $\mathrm{p}<0.001$ & $\mathrm{p}<0.001$ \\
Type of distribution & Underdispersed & Overdispersed & Overdispersed \\
Goodness of fit to & & $\chi^{2}{ }_{6}=8.69$, & $\chi^{2}{ }_{3}=1.795$, \\
negative binomial distr. & & $\mathrm{p}=0.192$ & $\mathrm{p}=0.578$ \\
\hline
\end{tabular}

(Ancylomenes pedersoni, Periclimenes yucatanicus, and $P$. rathbunae) on the back reef, and to $P$. yucatanicus in the reef channels (Fig. 6a). Degree of affinity for host and use of
space provided by host

Alpheus armatus and Ancylomenes pedersoni exhibited a high affinity for Bartholomea annulata (Fig. 6b), but the former showed a strong tendency to occur under the host, whereas the latter was more often found on or near the host (Fig. 6c). Periclimenes rathbunae showed a high affinity for Lebrunia danae (Fig. 6b) and tended to occur on or under the host (Fig. 6c). Thor amboinensis and Mithraculus cinctimanus were mostly associated with Condylactis gigantea, but many were also found with $L$. danae or B. annulata (Fig. 6b). These 2 symbionts, in particular $M$. cinctimanus, occurred more often under the host (Fig. 6c). P. yucatanicus exhibited a rather low degree of host affinity, with $41 \%$ individuals associated with C. gigantea, $39 \%$ with L. danae, and $20 \%$ with B. annulata (Fig. 6b), and showed a similar pattern of host space use as in Ancylomenes pedersoni, with most individuals occurring on or near the host (Fig. 6c).

Season did not affect the degree of host affinity for any symbiont (contingency table analyses, range in p-values: 0.109 to 0.918 ), or the pattern of host space use for Mithraculus cinctimanus $\left(\chi_{6}^{2}=8.874, \mathrm{p}=0.181\right)$, Periclimenes rathbunae $\left(\chi_{6}^{2}=8.656, \mathrm{p}=\right.$ $0.194)$, or $P$. yucatanicus $\left(\chi_{6}^{2}=11.659\right.$, $\mathrm{p}=0.07)$. However, there was signifi-

teraction effect between these 2 variables (Table 5). On average, Alpheus armatus was much more abundant than the other 5 symbionts. All interaction effects with RZ were non-significant (Table 5), indicating that the relative density of each symbiont by reef zone remained rather stable over time. Thus, by reef zone, the highest densities corresponded to Alpheus armatus on the back reef and in reef channels, while the lowest densities corresponded to the 3 palaemonids cant seasonal variation in host space use by Alpheus armatus $\left(\chi_{6}^{2}=40.190, \mathrm{p}<0.001\right)$, Ancylomenes pedersoni $\left(\chi_{6}^{2}=18.726, \mathrm{p}=0.005\right)$, and Thor amboinensis $\left(\chi_{6}^{2}=25.397, \mathrm{p}<0.001\right)$. In Alpheus armatus, this variability reflected changes in the proportions of individuals located under or near the host, and in Ancylomenes pedersoni and $T$. amboinensis, it reflected changes in the proportions of individuals located near or on the host. 
Table 4. Bartholomea annulata, Condylactis gigantea, and Lebrunia danae. Crustacean species and numbers of individuals observed to associate with 3 sea anemone host species. Symbiotic species establish long-term associations with hosts, while facultative associates are primarily free-living but may associate with anemones for brief periods (Ross 1983, Gwaltney \& Brooks 1994)

\begin{tabular}{|c|c|c|c|c|}
\hline \multirow[t]{2}{*}{ Crustacean species } & \multicolumn{4}{|c|}{ Host anemone species } \\
\hline & $\begin{array}{c}B . \\
\text { annulata }\end{array}$ & $\begin{array}{c}C . \\
\text { gigantea }\end{array}$ & $\begin{array}{c}L . \\
\text { danae }\end{array}$ & Total \\
\hline \multicolumn{5}{|l|}{ Symbionts } \\
\hline Alpheus armatus & 598 & 2 & 3 & 603 \\
\hline Thor amboinensis & 15 & 167 & 59 & 241 \\
\hline Ancylomenes pedersoni & 158 & 3 & 5 & 166 \\
\hline Mithraculus cinctimanus & 48 & 84 & 29 & 161 \\
\hline Periclimenes yucatanicus & 14 & 22 & 25 & 61 \\
\hline Periclimenes rathbunae & 2 & 6 & 45 & 53 \\
\hline Subtotal & 835 & 284 & 166 & 1285 \\
\hline \multicolumn{5}{|l|}{ Facultative associates } \\
\hline Stenorhynchus seticornis & 26 & 19 & 0 & 45 \\
\hline Mithrax sp. & 1 & 6 & 6 & 13 \\
\hline Mithraculus sculptus & 1 & 5 & 1 & 7 \\
\hline Stenopus hispidus & 3 & 2 & 0 & 5 \\
\hline Mithrax pilosus & 2 & 1 & 1 & 4 \\
\hline Mithraculus forceps & 1 & 2 & 0 & 3 \\
\hline Macrocoeloma trispinosum & 2 & 1 & 0 & 3 \\
\hline Brachycarpus biunguiculatus & 2 & 1 & 0 & 3 \\
\hline Cinetorhynchus rigens & 1 & 1 & 1 & 3 \\
\hline Subtotal & 39 & 38 & 9 & 86 \\
\hline Total & 874 & 322 & 175 & 1371 \\
\hline
\end{tabular}

Up to 3 species of symbionts coexisted on 98 individuals of Bartholomea annulata $(16 \%$ of all $B$. annulata that harbored crustaceans), 42 of Condylactis gigantea (31\%), and 20 of Lebrunia danae (15\%) (Fig. 7). L. danae harbored 11 different commensal complexes, but none were particularly frequent. B. annulata harbored 8 different commensal complexes, of which the most frequent (86\%) was constituted by Alpheus armatus and Ancylomenes pedersoni, the 2 symbionts with the highest affinity for this host (Fig. 7a). Coexisting individuals of Alpheus armatus and Ancylomenes pedersoni were invariably in different places relative to the host (under and on the host, respectively, or under and near the host). Six commensal complexes occurred in C. gigantea, with the most frequent $(62 \%)$ also consisting of the 2 symbiontic species with the greatest affinity for this host: Thor amboinensis and Mithraculus cinctimanus

Table 5. Repeated-measures ANOVA of crustacean symbiont density $\left(\ln [\mathrm{n}+1] 0.25 \mathrm{ha}^{-1}\right)$ with crustacean species (CS; 6 levels corresponding to 6 species of crustacean symbionts) and reef zone (RZ; back reef, reef channels, fore reef) over time ( $T$; spring, summer, autumn, winter)

\begin{tabular}{|lrrrr|}
\hline Effect & df & \multicolumn{1}{c}{ MS } & $F$ & $p$ \\
\hline Intercept & 1 & 357.702 & 161.030 & $<0.001$ \\
CS & 5 & 21.887 & 9.853 & $<0.001$ \\
RZ & 2 & 2.718 & 1.224 & 0.306 \\
CS $\times$ RZ & 10 & 2.704 & 1.217 & 0.313 \\
Error & 36 & 0.504 & & \\
T & 3 & 1.695 & 6.193 & 0.001 \\
T $\times$ CS & 15 & 0.537 & 1.960 & 0.025 \\
T $\times$ RZ & 6 & 0.418 & 1.527 & 0.176 \\
T $\times$ CS $\times$ RZ & 30 & 0.242 & 0.884 & 0.641 \\
Error & 108 & 0.274 & & \\
\hline
\end{tabular}

Conspecific groups and commensal complexes

Alpheus armatus, Periclimenes yucatanicus, $P$. rathbunae, and Mithraculus cinctimanus were consistently found alone or in pairs on the same host (Table 6). In contrast, groups of $>2$ conspecifics on the same host occurred more often than expected by chance for Thor amboinensis (up to 6 ind., $\chi_{3}^{2}=$ 22.646, p < 0.001) and Ancylomenes pedersoni (up to 4 ind., $\left.\chi^{2}{ }_{1}=7.495, \mathrm{p}=0.006\right)$.
(Fig. 7b). However, in this case, the 2 symbionts were often under the host at the same time.

\section{DISCUSSION}

\section{Host anemones}

The anemones Bartholomea annulata, Condylactis gigantea, and Lebrunia danae occur on coral reefs throughout the Caribbean region, but their relative abundance varies widely with geographic area and local habitat features (e.g. Panamá: Sebens 1976; Colombia: Barrios-Suárez et al. 2002; Hispaniola: Herrera-Moreno \& Betancourt-Fernández 2002). In the PMCR, B. annulata is the most abundant and $C$. gigantea the least abundant of these 3 anemone species, but the density distribution of each species by reef zone remains rather stable over time, suggesting that these sessile organisms quickly acclimate to local microhabitats. However, reef zone differently affects the density and size of $B$. annulata and $C$. gigantea, and the density but not the size of $L$. danae. These contrasting results may reflect interspecific differences in susceptibility to local environmental features (e.g. the flow regime, which may vary in effects on feeding efficiency with anemone size), 

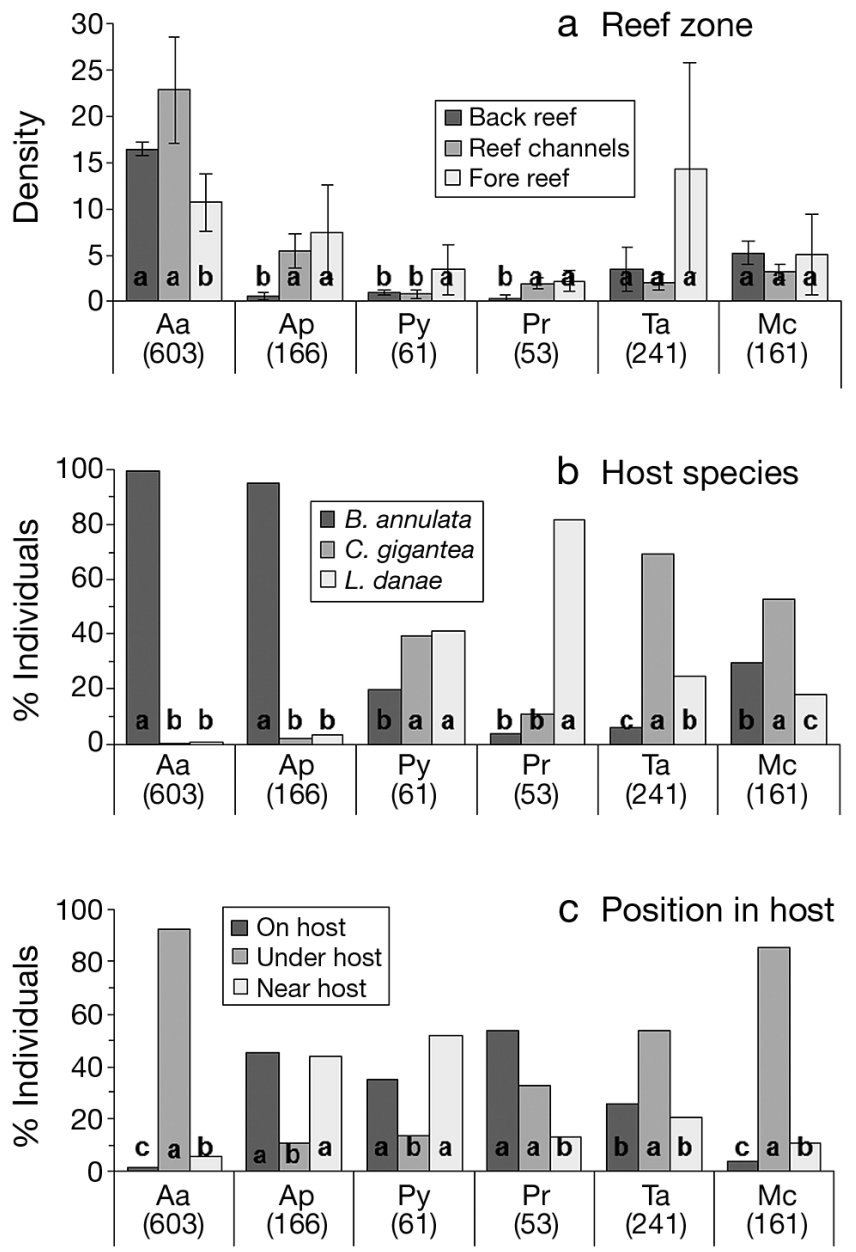

Fig. 6. Bartholomea annulata, Condylactis gigantea, and Lebrunia danae. (a) Density (ind. $0.25 \mathrm{ha}^{-1}$, mean $\pm \mathrm{SE}$ ) of crustacean symbionts by reef zone, (b) percentages of individuals of each species distributed among 3 species of host anemones, and (c) 3 positions on hosts. Similar letters in columns for each species denote statistically similar groups. Numbers in () on $x$-axes denote sample sizes. Aa: Alpheus armatus; Ap: Ancylomenes pedersoni; Py: Periclimenes yucatanicus; Pr: P. rathbunae; Ta: Thor amboinensis; Mc: Mithraculus cinctimanus

microhabitat requirements, reproductive strategy, and photosynthetic efficiency of dinoflagellate endosymbionts borne by these cnidarians.

Because anemones depend on water flow to bring them food, but risk being dislodged or broken by drag forces (Koehl 1977), their dimensions in a given flow habitat involve a trade-off between maximizing food availability and minimizing flow forces and physical stress (Anthony 1997). Although anemones can reduce drag by retracting, and many are capable of polyp shrinkage, maximum feeding efficiencies are attained by small anemones at high flow regimes, and by large anemones at slow flow regimes
Table 6. Group sizes of conspecific crustacean symbionts co-occurring on the same host anemone individuals

\begin{tabular}{|lrrrrrrrr|}
\hline \multirow{2}{*}{ Crustacean species } & \multicolumn{8}{c|}{ Group size } \\
\cline { 2 - 8 } & 1 & 2 & 3 & 4 & 5 & 6 \\
\hline Alpheus armatus & 429 & 87 & - & - & - & - \\
Thor amboinensis & 80 & 27 & 15 & 6 & 4 & 3 \\
Ancylomenes pedersoni & 100 & 17 & 8 & 2 & - & - \\
Mithraculus cinctimanus & 149 & 6 & - & - & - & - \\
Periclimenes yucatanicus & 43 & 9 & - & - & - & - \\
Periclimenes rathbunae & 47 & 3 & - & - & - & - \\
\hline
\end{tabular}
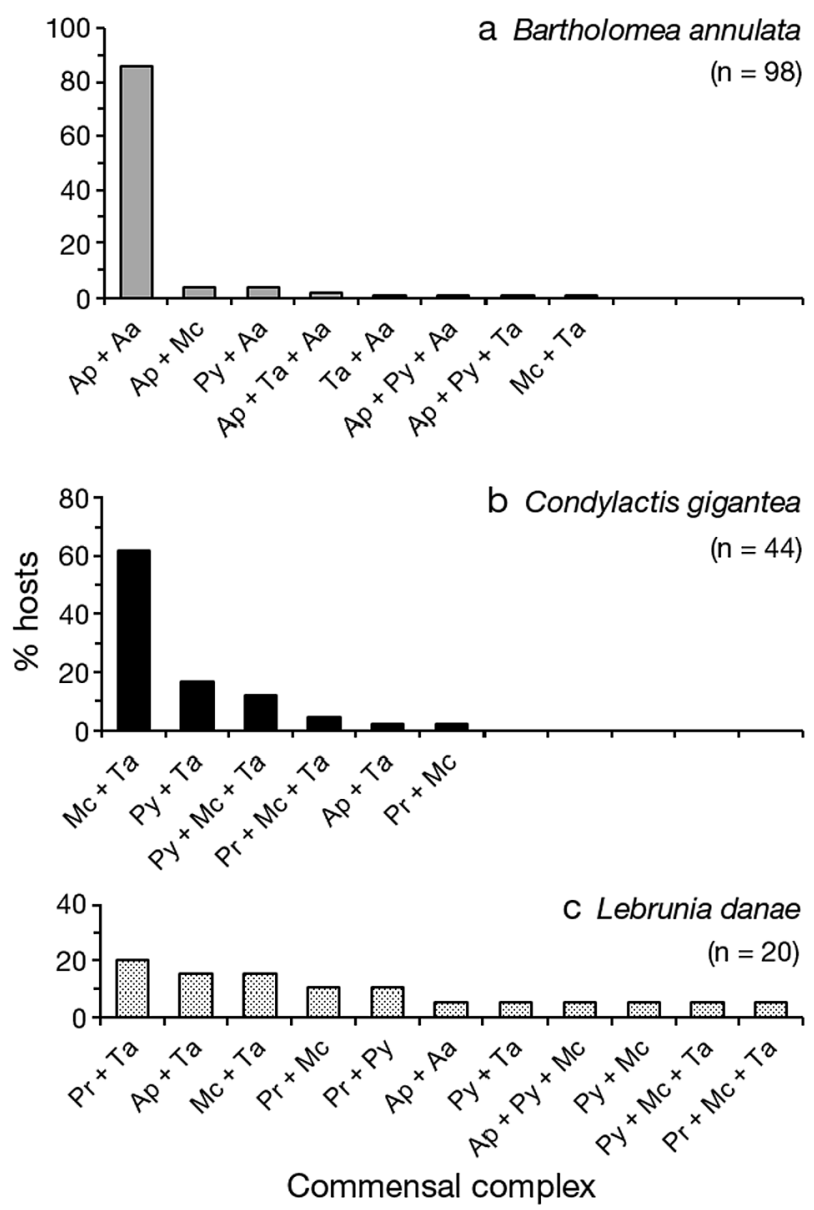

Fig. 7. Bartholomea annulata, Condylactis gigantea, and Lebrunia danae. Diversity and percent frequency of commensal complexes in hosts harboring $>1$ symbiont species: (a) B. annulata, (b) C. gigantea, and (c) L. danae. Abbreviations for symbiotic crustacean species as in Fig. 6

(Anthony 1997, Titus 2011). In the PMCR, water enters the reef lagoon via waves breaking on the coral reef and exits the lagoon through large reef channels. This circulation regime ensures good flushing (average turnover time: $2.25 \mathrm{~h}$; Coronado et al. 2007), but results in high levels of water motion 
and sediment re-suspension in the shallow back reef (Ruiz-Rentería et al. 1998), and in a high flow regime through the reef channels (average current velocity: $20 \mathrm{~cm} \mathrm{~s}^{-1}$ ) compared to the fore reef (2 to $3 \mathrm{~cm} \mathrm{~s}^{-1}$; Coronado et al. 2007), potentially explaining the generally smaller size of anemones on the back reef and in reef channels relative to the fore reef.

The dinoflagellate genus Symbiodinium comprises several types within 8 subgeneric clades or lineages (A to $\mathrm{H}$ ), and the types borne by a particular host species may vary with geographical location (Venn et al. 2008). In the PMCR, a variety of cnidarian hosts living at depths of 0 to $15 \mathrm{~m}$, including Bartholomea annulata and Lebrunia danae, bear exclusively Symbiodinium type $\mathrm{C} 1$, suggesting that this type has a relatively high degree of photosynthetic plasticity (LaJeunesse 2002). However, B. annulata strongly tends to occupy crevices in sand pockets (e.g. Sebens 1976, Barrios-Suárez et al. 2002), a type of microhabitat that is more common in the back reef and reef channels than in the fore reef (Ruiz-Rentería et al. 1998). Moreover, individuals of $B$. annulata spawn twice a year but also undergo pedal laceration, a type of clonal replication that helps to maintain habitat space and stable population sizes (Jennison 1981, Titus 2011). In the laboratory, small B. annulata $\left(<28 \mathrm{~cm}^{2}\right.$ TCSA) replicate by pedal laceration more often than larger conspecifics (Titus 2011), while in the field, $B$. annulata replicate more frequently on near-shore reefs exposed to more suspended particulate matter than on offshore reefs with less sedimentation and more light penetration (Nelsen 2008). In conjunction, these features of $B$. annulata may underlie its greater density, but smaller mean size, in the reef channels and back reef relative to the fore reef. We found no information on the reproductive strategy of $L$. danae, but a congeneric species, L. coralligens, releases larvae that are negatively phototropic, show aggregated settlement behavior, and settle most frequently around the bases of the adults, with settlement and metamorphosis occurring within $24 \mathrm{~h}$ (Lewis 1984). If L. danae shows similar reproductive and settlement strategies as L. coralligens, these features might account for the similar size distribution and mean size of $L$. danae in all 3 reef zones. However, L. danae occupies crevices in hard substrates and rarely occurs at depths $<5 \mathrm{~m}$ (Herrnkind et al. 1976, Sebens 1976, Herrera-Moreno \& Betancourt-Fernández 2002), explaining its greater densities in the fore reef and reef channels relative to the back reef.

In the PMCR, Symbiodinium clade-A types are more constrained to hosts living within 0 to $5 \mathrm{~m}$ depth below the water surface, suggesting photoacclimation to high irradiance, and Condylactis gigantea bears a mixture of types A4a, C1, and A3 (LaJeunesse 2002). This may explain the rather patchy distribution of $C$. gigantea and its generally lower densities in reef channels. On the other hand, because this species reproduces only sexually with individuals spawning once per year but over a prolonged reproductive period (Jennison 1981), the multimodal size distribution of C. gigantea in all 3 reef zones likely reflects different pulses in larval recruitment.

Crustacean associates occurred in a far higher proportion of individuals of Bartholomea annulata $(72.8 \%)$ and Condylactis gigantea $(70.7 \%)$ than they did in Lebrunia danae (27.2\%). Stanton (1977) also found crustaceans in only $26 \%$ of $L$. danae in his study area in the Bahamas. Although both the probability of harboring at least 1 crustacean and the number of crustaceans per individual anemone increased with size in all 3 host species, individuals of C. gigantea harbored, on average, 1.6 and 4.5 times as many crustaceans as did individuals of $B$. annulata and $L$. danae, respectively. This result cannot be entirely ascribed to the comparatively larger size of $C$. gigantea, because the mean sizes of $L$. danae and $B$. annulata were similar. However, as $C$. gigantea and $B$. annulata bear most of their dinoflagellate endosymbionts within their feeding tentacles, these anemones tend to remain continuously expanded so as to maximize light capture during the day and prey capture during the night (Sebens \& DeRiemer 1977), potentially providing relatively stable habitats for their crustacean associates. By contrast, L. danae, in addition to having larger nematocysts and producing more potent toxic compounds than other sea anemones (Herrnkind et al. 1976, Sánchez-Rodríguez \& Cruz-Vázquez 2006), contains most of its endosymbionts within auxiliary structures ('pseudotentacles') that are incapable of feeding behavior. Thus, during the day, the pseudotentacles are expanded and the feeding tentacles contracted, while the opposite occurs at night (Sebens \& DeRiemer 1977, Stanton 1977). In conjunction, these features of $L$. danae may provide a less stable or less suitable habitat for crustacean associates.

\section{Crustacean symbionts}

The vast majority (93.8\%) of the crustacean associates of these anemones belonged to 6 species of symbionts. Although the 6 symbiont species occurred in all 3 host species, some exhibited a high 
degree of affinity for a host species. A variety of commensal complexes were found in the 3 host species, reflecting differences in intra- and interspecific behavioral interactions and microhabitat requirements among symbionts (Herrnkind et al. 1976, Mercado \& Capriles 1982, Wirtz 1997). Interestingly, the highest diversity of commensal complexes occurred in Lebrunia danae, the host with the lowest proportion of individuals harboring crustaceans, and the lowest diversity occurred in Condylactis gigantea, the host with the largest mean size and a high proportion of individuals harboring crustaceans.

The most abundant symbiont by far was Alpheus armatus. This alpheid shrimp is generally considered an obligate symbiont of Bartholomea annulata (Knowlton 1980, Knowlton \& Keller 1983), although field (Herrnkind et al. 1976) and laboratory studies (Knowlton \& Keller 1985) suggest that it may also use other hosts, at least briefly. In our study, $99 \%$ of the A. armatus $(\mathrm{n}=603)$ associated with $B$. annulata, but 3 ind. associated with Lebrunia danae and 2 with Condylactis gigantea. These shrimps live in the same cavity as their host and are highly territorial, especially the juveniles, whereas the adults may share their host only with a conspecific of the opposite sex (Limbaugh et al. 1961, Knowlton 1980, Knowlton \& Keller 1983). Indeed, $90 \%$ of the $A$. armatus that we observed were under the host, and $71 \%$ were dwelling alone, and the rest in pairs. The high degree of affinity of $A$. armatus for $B$. annulata, and its tendency to dwell alone, resulted in a similar density distribution by reef zone of these 2 species.

Ancylomenes pedersoni also exhibited a high degree of affinity for Bartholomea annulata, yet these 2 species differed in their density distribution by reef zone. This result reflects the tendency of Ancylomenes pedersoni to form groups and its ability to acclimate to different hosts in the absence of $B$. annulata (e.g. Silbiger \& Childress 2008, Mascaró et al. 2012), as well as the lower probability of finding crustacean associates in $B$. annulata in the reef channels (where this anemone exhibited the highest densities). The high frequency of coexistence of Ancylomenes pedersoni and Alpheus armatus in $B$. annulata appears related to the inverse pattern of host space use exhibited by these 2 symbionts. Periclimenes rathbunae exhibited a strong affinity for Lebrunia danae, and because these shrimps occurred alone or in pairs in the same host, the density distribution by reef zone was similar for these 2 species. In other locations, $P$. rathbunae is strongly associated with the sun anemone Stichodactyla helianthus (Hayes \& Trimm 2008, Silbiger \& Childress 2008), a species that was absent from our study sites because, in the PMCR, it occurs only on the reef crest at depths of 0.5 to $1.5 \mathrm{~m}$ (González-Muñoz 2009). P. yucatanicus occurred in similar percentages on Condylactis gigantea and L. danae, and to a lesser extent on $B$. annulata. In Florida, $P$. yucatanicus was strongly associated with $C$. gigantea and only occurred on $B$. annulata when $C$. gigantea was scarce (Silbiger \& Childress 2008).

Ancylomenes pedersoni and Periclimenes yucatanicus both potentially serve as cleaner shrimps (Limbaugh et al. 1961, Bunkley-Williams \& Williams 1998), although the former performs this activity more effectively than the latter (McCammon et al. 2010). It has been suggested that anemones harboring multiple $A$. pedersoni might be more easily identified as 'cleaning stations' by reef fishes, and that this might explain the tendency of $A$. pedersoni to occur in groups on the same host (Limbaugh et al. 1961, Herrnkind et al. 1976, Huebner \& Chadwick 2012a). However, Huebner \& Chadwick (2012b) found that the size of the anemone Bartholomea annulata rather than the number of associated $A$. pedersoni acts as a primary attractant to client fishes. Also, social interactions may influence group size and the distribution of conspecific cleaner shrimps among hosts (Limbaugh et al. 1961, Mahnken 1972, Wicksten 1995). This may also occur in P. rathbunae, a non-cleaner shrimp, which has been found alone or in pairs on the same host in some locations (e.g. Mahnken 1972, the present study), and in groups of up to $11 \mathrm{ind}$. on the same host in other locations (e.g. Mercado \& Capriles 1982, Hayes \& Trimm 2008).

Although heterospecific palaemonids can coexist on the same host (Mahnken 1972, Stanton 1977, Williams \& Bunkley-Williams 2000), we observed coexistence of Ancylomenes pedersoni and Periclimenes yucatanicus on only 2 Bartholomea annulata and 1 Lebrunia danae, and coexistence of $P$. rathbunae and $P$. yucatanicus on only $2 L$. danae. In all cases, heterospecific shrimps were on different parts of the host, suggesting some degree of interspecific competition for microhabitat, in particular between A. pedersoni and P. yucatanicus, given their similar pattern of host space use. We did not observe coexistence of $A$. pedersoni and $P$. rathbunae, but this was possibly due to the high affinity for different hosts exhibited by these 2 palaemonids.

Thor amboinensis was the second most abundant symbiont in our study sites, and these small hippolytid shrimps associated mostly with Condylactis 
gigantea ( $70 \%$ of all shrimps on this host), with up to 6 individuals co-occurring in a single host. In general, $T$. amboinensis occurs in groups more often than expected by chance alone (Wirtz 1997, Baeza \& Piantoni 2010, the present study), potentially reflecting the small size and limited defensive capability of these shrimps, which may preclude solitary individuals from monopolizing the host (Thiel \& Baeza 2001). $T$. amboinensis occurred in many different commensal complexes on all 3 host species, and coexisted, often side by side, with each of the other 5 symbionts, as observed also in Puerto Rico (Mercado \& Capriles 1982).

Over $50 \%$ of the small commensal crabs Mithraculus cinctimanus associated with Condylactis gigantea, and the rest with either of the other 2 hosts. Patton (1979) remarked that these majid crabs are usually solitary on hosts, and only occasionally occur in pairs, as we found in the present study. Most crabs were located under the host, a similar pattern as that of $M$. commensalis crabs associated with Lebrunia danae in the Bahamas (Herrnkind et al. 1976). However, according to Patton (1979), M. commensalis (first described by Manning 1970) is actually the juvenile phase of $M$. cinctimanus, and according to Wagner (1990), only the juveniles are symbiotic with anemones, whereas the adults are free-living. In our study, M. cinctimanus coexisted with all other symbionts except Alpheus armatus, possibly because these 2 symbionts exhibited a very similar pattern of host space use, and the highly territorial and aggressive alpheid can easily displace the smaller crab from a host (Knowlton 1980).

In summary, we found substantial variability in several ecological features of 3 species of host anemones and 6 species of their crustacean symbionts in the PMCR. These findings are relevant, because even though the PMCR was declared a national park in 1998, effectively protecting these animals from being extracted for the aquarium trade (Instituto Nacional de Ecología 2000), it is very close to a shore with one of the highest rates of touristic and urban development in Mexico (Rodríguez-Martínez 2008). Time-series ecological data from local sea grass and reef communities have detected gradual changes over time that may reflect an increase in pollution caused by the rapid rise in urban and tourist development along the coast and inland from Puerto Morelos, coupled with poor water-management practices (Rodríguez-Martínez et al. 2010, van Tussenbroek 2011). Coastal development also tends to increase water turbidity, especially in shallow reef lagoons and back-reef areas (Fourqurean \& Robblee 1999,
Sullivan-Sealy 2004), potentially altering the distribution and abundance of anemones by affecting their mean size and rate of clonal replication, and photosynthetic efficiency of their endosymbionts (SullivanSealy 2004, Nelsen 2008). This might further impact their crustacean symbionts, in particular those that exhibit a high affinity for a given host species (e.g. Alpheus armatus), and those that serve as cleaning shrimps, which depend on large hosts to attract fish clients, with potential cascading effects on the coral reef system (Mahnken 1972, Huebner \& Chadwick $2012 b)$. Therefore, the present study provides baseline information to further assess the potential influences of local (e.g. coastal development and pollution) and global (e.g. climate change) anthropogenic stressors on anemone-crustacean symbioses.

Acknowledgements. We thank Erika Magallón-Gayón for helping with the fieldwork and Universidad Nacional Autónoma de México for funding. The Consejo Nacional de Ciencia y Tecnología (México) provided an MSc studentship to M.P.O. Annual permits to conduct fieldwork within the National Park 'Arrecifes de Puerto Morelos' were issued by Comisión Nacional de Acuacultura y Pesca and validated by Comisión Nacional de Áreas Naturales Protegidas.

\section{LITERATURE CITED}

Anthony KRN (1997) Prey capture by the sea anemone Metridium senile (L.): effects of body size, flow regime, and upstream neighbors. Biol Bull (Woods Hole) 192: 73-86

Baeza JA, Piantoni C (2010) Sexual system, sex ratio, and group living in the shrimp Thor amboinensis (De Man): relevance to resource-monopolization and sex-allocation theories. Biol Bull (Woods Hole) 219:151-165

Barrios-Suárez LM, Reyes JO, Navas GR, García CB (2002) Distribution of anemones (Anthozoa: Actiniaria y Corallimorpharia) in the area of Santa Marta, Colombian Caribbean. Cienc Mar 28:37-48

Briones-Fourzán P, Lozano-Álvarez E (2002) Shallow-water benthic decapod crustaceans of Chankanaab Park, Cozumel Island, México. In: Escobar-Briones E, Álvarez F (eds) Modern approaches to the study of crustaceans. Kluwer, Amsterdam, p 197-204

Bunkley-Williams L, Williams EH Jr (1998) Ability of Pederson cleaner shrimp to remove juveniles of the parasitic cymothoid isopod, Anilocra haemuli, from the host. Crustaceana 71:862-869

Calado RJ, Dionisio G, Dinis MT (2002) Decapod crustaceans associated with the snakelock anemone Anemonia sulcata. Living there or just passing by? Sci Mar 71: 287-292

Chace FA Jr (1972) The shrimps of the Smithsonian-Bredin Caribbean Expeditions with summary of the West Indian shallow-water species (Crustacea: Decapoda: Natantia). Smithson Contrib Zool 98:1-179

Cohen AJ Jr (1960) Estimating the parameter in a conditional Poisson distribution. Biometrics 16:203-211 
Coronado C, Candela J, Iglesias-Prieto R, Sheinbaum J, López M, Ocampo-Torres FJ (2007) On the circulation in the Puerto Morelos fringing reef lagoon. Coral Reefs 26: 149-163

Crawford JA (1992) Acclimation of the shrimp, Periclimenes anthophilus, to the giant sea anemone Condylactis gigantea. Bull Mar Sci 50:331-341

- Fautin DG, Guo CC, Hwang JS (1995) Costs and benefits of the symbiosis between the anemoneshrimp Periclimenes brevicarpalis and its host Entacmaea quadricolor. Mar Ecol Prog Ser 129:77-84

Fourqurean JW, Robblee MB (1999) Florida Bay: a history of recent ecological changes. Estuaries 22:345-357

Giese C, Mebs D, Werding B (1996) Resistance and vulnerability of crustaceans to cytolytic sea anemone toxins. Toxicon 34:955-958

Glynn PW, Enochs IC (2011) Invertebrates and their roles in coral reef ecosystems. In: Dubinsky Z, Stambler N (eds) Coral reefs: an ecosystem in transition. Springer, Berlin, p 273-325

González-Muñoz RE (2009) Anémonas (Anthozoa: Actiniaria, Corallimorpharia y Zoanthidea) del arrecife de Puerto Morelos, Quintana Roo. MSc thesis, Universidad Nacional Autónoma de México, Mexico City

Gwaltney CL, Brooks WR (1994) Host specificity of the anemone shrimps Periclimenes pedersoni and P. yucatanicus in the Florida Keys. Symbiosis 16:83-93

> Hattori A (2002) Small and large anemonefishes can coexist using the same patchy resources on a coral reef, before habitat destruction. J Anim Ecol 71:824-831

Hayes FE, Trimm NA (2008) Distributional ecology of the anemone shrimp Periclimenes rathbunae associating with the sea anemone Stichodactyla helianthus at Tobago, West Indies. Nauplius 16:73-77

Herrera-Moreno A, Betancourt-Fernández L (2002) Especies de anémonas (Coelenterata: Actiniaria: Corallimorpharia, Zoanthidea y Ceriantharia) conocidas para la Hispaniola. Rev Cienc Soc (Santo Domingo) 27:439-453

Herrnkind W, Stanton G, Conklin E (1976) Initial characterization of the commensal complex associated with the anemone Lebrunia danae at Grand Bahama. Bull Mar Sci 26:65-71

Howell DC (2002) Statistical methods for psychology, 5th edn. Duxbury, Pacific Grove, CA

Huebner LK, Chadwick NE (2012a) Patterns of cleaning behaviour on coral reef fish by the anemoneshrimp Ancylomenes pedersoni. J Mar Biol Assoc UK 92:1557-1562

> Huebner LK, Chadwick NE (2012b) Reef fishes use sea anemones as visual cues for cleaning interactions with shrimp. J Exp Mar Biol Ecol 416-417:237-242

Instituto Nacional de Ecología (2000) Programa de manejo del Parque Nacional Arrecife de Puerto Morelos. Secretaría de Medio Ambiente, Recursos Naturales y Pesca, México, DF

> Jennison BL (1981) Reproduction in three species of sea anemones from Key West, Florida. Can J Zool 59: 1708-1719

Jordán-Dahlgren E (1989) Efecto de la morfología del sustrato en el desarrollo de la comunidad coralina. An Inst Cienc Mar Limnol Univ Nac Auton Mex 16:105-118

Jordán-Dahlgren E, Rodríguez-Martínez R (2003) The Atlantic coral reefs of Mexico. In: Cortés J (ed) Latin American coral reefs. Elsevier, Amsterdam, p 131-158

Khan RN, Becker JHA, Crowther AL, Lawn ID (2004) Spatial distribution of symbiotic shrimps (Periclimenes holthuisi,
P. brevicarpalis, Thor amboinensis) on the sea anemone Stichodactyla haddoni. J Mar Biol Assoc UK 84:201-203

Knowlton N (1980) Sexual selection and dimorphism in two demes of a symbiotic, pair-bonding snapping shrimp. Evolution 34:161-173

Knowlton N, Keller BD (1983) A new, sibling species of snapping shrimp associated with the Caribbean sea anemone Bartholomea annulata. Bull Mar Sci 33:353-362

Knowlton N, Keller BD (1985) Two more sibling species of alpheid shrimps associated with the Caribbean sea anemones Bartholomea annulata and Heteractis lucida. Bull Mar Sci 37:893-904

Koehl MAR (1977) Effects of sea anemones on the flow forces they encounter. J Exp Biol 69:87-105

> LaJeunesse TC (2002) Diversity and community structure of symbiotic dinoflagellates from Caribbean coral reefs. Mar Biol 141:387-400

Levine DM, Blanchard OJ (1980) Acclimation of two shrimps of the genus Periclimenes to sea anemones. Bull Mar Sci 30:460-466

Lewis JB (1984) Photosynthetic production by the coral reef anemone, Lebrunia coralligens Wilson, and behavioral correlates of two nutritional strategies. Biol Bull (Woods Hole) 167:601-612

Limbaugh C, Pederson D, Chace FA Jr (1961) Shrimps that clean fishes. Bull Mar Sci Gulf Caribb 11:237-257

Mahnken C (1972) Observations on cleaner shrimps of the genus Periclimenes. Nat Hist Mus Los Angeles County Sci Bull 14:71-83

> Manning R (1970) Mithrax (Mithraculus) commensalis, a new West Indian spider crab (Decapoda, Majidae) commensal with a sea anemone. Crustaceana 19:157-161

> Mascaró M, Rodríguez-Pestaña L, Chiappa-Carrara X, Simões N (2012) Host selection by the cleaner shrimp Ancylomenes pedersoni: do anemone host species, prior experience or the presence of conspecific shrimp matter? J Exp Mar Biol Ecol 413:87-93

McCammon A, Sikkel PC, Nemeth D (2010) Effects of three Caribbean cleaner shrimps on ectoparasitic monogeneans in a semi-natural environment. Coral Reefs 29: 419-426

Mercado LM, Capriles VA (1982) Description of two commensal complexes associated with the anemones Stoichactis helianthus and Homostichanthus duerdeni in Puerto Rico. Caribb J Sci 17:69-72

Monroy-Velázquez LV (2000) Variaciones en la composición y abundancia de la fauna de decápodos asociados a pastizales marinos en el Caribe mexicano. MSc thesis, Universidad Nacional Autónoma de México, Mexico City

Nelsen MW (2008) Population dynamic modeling of the corkscrew anemone Bartholomea annulata on Caribbean coral reefs. MSc thesis, Auburn University, Auburn, AL

Nizinski MS (1989) Ecological distribution, demography and behavioral observations on Periclimenes anthophilus, an atypical symbiotic cleaner shrimp. Bull Mar Sci 45: $174-188$

Okuno J, Bruce AJ (2010) Designation of Ancylomenes gen. nov. for the 'Periclimenes aesopius species group' (Crustacea: Decapoda: Palaemonidae), with the description of a new species and a checklist of congeneric species. Zootaxa 2372:85-105

Patton WK (1979) On the association of the spider crab, Mithrax (Mithraculus) cinctimanus (Stimpson) with Jamaican sea anemones. Crustaceana (Suppl 5):55-61 
Quinn GP, Keough MJ (2002) Experimental design and data analysis for biologists. Cambridge University Press, Cambridge

Reaka ML, Rodgers PJ, Kudla AU (2008) Patterns of biodiversity and endemism on Indo-West Pacific coral reefs. Proc Natl Acad Sci USA 105(Suppl 1):11474-11481

Rodríguez-Martínez RE (2008) Community involvement in marine protected areas: the case of Puerto Morelos reef, Mexico. J Environ Manag 88:1151-1160

Rodríguez-Martínez RE, Ruíz-Rentería F, van Tussenbroek B, Barba-Santos G, Escalante-Mancera E, Jordán-Garza G, Jordán-Dahlgren E (2010) Environmental state and tendencies of the Puerto Morelos CARICOMP site, Mexico. Rev Biol Trop 58(Suppl 3):23-43

Ross DM (1983) Symbiotic relations. In: Vernberg SJ, Vernberg WB (eds) The biology of Crustacea, Vol 7. Academic Press, New York, NY, p 163-212

Ruiz-Rentería F, van Tussenbroek BI, Jordán-Dahlgren E (1998) Puerto Morelos, Quintana Roo, México. In: Kjerve $\mathrm{BC}$ (ed) Caribbean coastal marine productivity (CARICOMP): coral reef, seagrass, and mangrove site characteristics. UNESCO, Paris, p 57-66

Sánchez-Rodríguez J, Cruz-Vázquez K (2006) Isolation and biological characterization of neurotoxic compounds from the sea anemone Lebrunia danae (Duchassaing \& Michelotti, 1860). Arch Toxicol 80:436-441

Sargent RC, Wagenbach GE (1975) Cleaning behavior of the shrimp Periclimenes anthophilus Holthuis and EiblEibesfeldt (Crustacea: Decapoda: Natantia). Bull Mar Sci 25:466-472

Sebens KP (1976) The ecology of Caribbean sea anemones in Panama: utilization of space on a coral reef. In: Mackie GO (ed) Coelenterate ecology and behavior. Plenum Press, New York, NY, p 67-77

Sebens KP, DeRiemer K (1977) Diel cycles of expansion and contraction in coral reef anthozoans. Mar Biol 43: 247-256

Silbiger NJ, Childress MJ (2008) Interspecific variation in anemone shrimp distribution and host selection in the Florida Keys (USA): implications for marine conservation. Bull Mar Sci 83:329-345

Stanton G (1977) Habitat partitioning among associated

Editorial responsibility: Peter Edmunds,

Northridge, California, USA decapods with Lebrunia danae at Grand Bahama. In: Taylor DL (ed) Proc 3rd Int Coral Reef Symp, Vol 1. Univ. of Miami, Miami, FL, p 169-175

Sullivan-Sealy K (2004) Large-scale ecological impacts of development on tropical island systems: comparison of developed and undeveloped islands in the central Bahamas. Bull Mar Sci 75:295-320

Thiel M, Baeza JA (2001) Factors affecting the social behaviour of crustaceans living symbiotically with other marine invertebrates: a modeling approach. Symbiosis 30:163-190

Titus BM (2011) Effects of habitat variation on life history traits and genetic structure in the corkscrew sea anemone Bartholomea annulata on Caribbean coral reefs. MSc thesis, Auburn University, Auburn, AL

Underwood AJ (1981) Techniques of analysis of variance in experimental marine biology and ecology. Oceanogr Mar Biol Annu Rev 19:513-605

van Tussenbroek BI (2011) Dynamics of seagrasses and associated algae in coral reef lagoons. Hidrobiológica 21: 293-310

- Venn AA, Loram JE, Trapido-Rosenthal HG, Joyce DA, Douglas AE (2008) Importance of time and place: patterns in abundance of Symbiodinium Clades A and B in the tropical sea anemone Condylactis gigantea. Biol Bull (Woods Hole) 215:243-252

Wagner HP (1990) The genera Mithrax Latreille, 1818 and Mithraculus White, 1847 (Crustacea: Brachyura: Majidae) in the Western Atlantic Ocean. Zool Verh 264:3-65

Wicksten MK (1995) Within-species variation in Periclimenes yucatanicus (Ives), with taxonomic remarks on $P$. pedersoni Chace (Crustacea: Decapoda: Caridea: Palaemonidae). Proc Biol Soc Wash 108:4548-4564

Williams H Jr, Bunkley-Williams L (2000) Experimental refutation of the ease of associate change by the spotted cleaner shrimp Periclimenes yucatanicus (Decapoda, Palaemonidae), new false-coral associates for the Pederson cleaner shrimp $P$. pedersoni, and general abundance of associations for both shrimps. Crustaceana 73:503-511

> Wirtz P (1997) Crustacean symbionts of the sea anemone Telmatactis cricoides at Madeira and the Canary Islands. J Zool 242:799-811

Submitted: July 2, 2012; Accepted: August 29, 2012 Proofs received from author(s): November 27, 2012 